\title{
Epileptic seizures in children with congenital Zika virus syndrome
}

\author{
Lucas Victor Alves 1 \\ Danielle Di Cavalcanti Sousa Cruz 2 \\ Ana Maria Campos van der Linden 3 \\ Ana Rodrigues Falbo 4 \\ Maria Júlia Gonçalves de Mello 5 \\ Camila Esteves Paredes 6 \\ Germanna Virginya Cavalcanti Silva 7 \\ José Natal Figueiroa 8 \\ Patrícia Gomes de Matos Bezerra 9
}

1,2,3,4,5,8,9 Instituto de Medicina Integral Prof. Fernando Figueira (IMIP). Rua dos Coelhos, 300. Recife, PE, Brasil. CEP: 50.070-550. E-mail: lucasvictor@hotmail.com 6,7 Faculdade Pernambucana de Saúde. Recife, PE, Brasil.

\begin{abstract}
Objectives: to describe preliminary data referred to epileptic seizures and the probability of occurring these epileptic seizures in the infants' first months of life with congenital Zika virus (ZIKV) syndrome.

Methods: concurrent cohort study including newborns and infants with congenital Zika virus syndrome attended at the specialized outpatient clinic at IMIP, Recife, Pernambuco, from October 2015 to May 2016.

Results: data on 106 infants were analyzed with confirmed or suspected association to ZIKV infection. Forty children (38.7\%) presented an epileptic seizure, classified at $43.3 \%$ of the cases as being spasms, $22.7 \%$ as generalized tonic seizures, $20.5 \%$ as partial and $4.5 \%$ other types of seizures. The median of days until the first report on the occurrence of epileptic seizure was 192 days of life.

Conclusions: children with congenital Zika virus syndrome presented a high incidence of epileptic seizures before the end of the first semester of life, and spasm was the epileptic seizure mostly observed.
\end{abstract}

Key words Zika virus, Microcephaly, Epilepsy 


\section{Introduction}

The change in the epidemiological pattern of newborns with microcephaly was observed mainly in the Northeast of Brazil, where an increase of cases were reported since August 2015. Until March 2016, the Brazilian Health Ministry received a notification of 6776 suspected cases 1,489 were confirmed.1,2 Pernambuco was the Brazilian State with the highest occurrence of microcephaly cases at this period. 3,4

An infected outbreak in pregnant women by Zika Virus (ZIKV), a flavivirus transmitted by Aedes aegypti mosquito, was associated to congenital microcephaly, one of the components of congenital Zika virus syndrome.5,6 ZIKV presents a tropism by the development of the nervous cells. Microcephaly is associated to alter in the cerebrum neuroimaging, including calcifications, ventriculomegaly and the abnormalities of white substance. 7 The neurological manifestations of these patients were not yet well described and epileptic seizures have been frequently reported by caregivers.

Epileptic seizures are described in other congenital infections ${ }^{8-11}$ such as toxoplasmosis, which its frequency is about $40 \%$, and cytomegalovirus is found in 4 to $11 \%$ of the symptomatic patients. On the other hand, the incidence of syphilis and herpes of epileptic seizures is much lower, although most commonly in meningitis. The objective of this research was to describe preliminary data referring to epileptic seizures and the probability of not occurring in the first months of life of the patients with congenital ZIKV syndrome.

\section{Methods}

A concurrent cohort study included newborns and infants with congenital Zika virus syndrome attended at a specialized outpatient clinic since October 26, 2015. These preliminary data refer to the follow up of this cohort until May 30, 2016 at the Instituto de Medicina Intergral Prof. Fernando Figueira (IMIP), a quaternary hospital located in Recife, Pernambuco, where contributed with a large number of notifications and established a multidisciplinary follow up plan for patients with congenital ZIKV virus syndrome.

Patients who presented cephalic perimeter (PC) or occipito-frontal circumference compatible to microcephaly were included in the study, according to the criteria initially determined by the Executive Secretary of Surveillance in Health (SEVS) of the Secretary of Health in Pernambuco (SES/PE), and by the Brazilian Ministry of Health (MS) and the World Health Organization (OMS/WHO), and/or patients suspected of fetopaty by ZIKV, born at IMIP (inborn) or those who came from other centers (outborn) and those that had a multi-professional follow up at IMIP for diagnostic investigation. ${ }^{8}$ In October 2015, SEVS made a compulsory notification of all the suspected cases of microcephaly in Pernambuco State, that is, all live births with PC equal to or less than $33 \mathrm{~cm}$; in December 2015, the definition of the case was altered for newborn with 37 to 42 weeks of gestation with PC equal to or less than $32 \mathrm{~cm}$ or for those with less than 37 weeks of gestation with $\mathrm{PC}$ equal to or less than 3 percentile (two standard deviations), considering Fenton's growth curve. In the second version of the Epidemiological and Clinic Protocol of the SES/PE and by the Ministry of Health and WHO protocol adopted the growth curve by WHO for the infants born at term whereas the cutoff point is $31.9 \mathrm{~cm}$ for boys and $31.5 \mathrm{~cm}$ for girls. The infants were monthly scheduled for follow ups by a team of pediatricians and neuro-pediatricians at the specialized outpatient clinic. Patients non-infected by ZIKV were excluded of this study, those with microcephaly associated to other etiologies and patients under diagnostic investigation.

It was taken in consideration that the patient was infected when the result of IgM - ELISA (Enzyme Linked ImmunoSorbent Assay) was positive and/or when the alterations of the neuroimages on the computerized tomography of the skull suggested a potential association to ZIKV infection.

The primary outcome studied was analyzed by the neuro-pediatrician in epileptic seizures through the mothers' reports and from the anti-epileptic medication institution in accordance to the type of epileptic seizures

An analysis of the frequency distribution for categorical variables and measurements of the central tendency and dispersion for continuous ones were performed. A survival curve was performed by using the Kaplan-Meier method to estimate the median age in the report of the first epileptic seizure, considering the moment it occurred in days from the date of birth up to the date of the first epileptic seizure (failure) at the medical consultation or the date of the last consultation for those who did not present epileptic seizures (censorship). The probabilities of survival during the follow up of the infants free of epileptic seizure were calculated.

This study was approved by the Ethics Committee in Human Being Research at IMIP (CAAE: 54701516.1.0000.5201). 


\section{Results}

During the data collecting period, 183 patients were referred to a specialized outpatient clinic. According to the diagnostic criteria described above, patients excluded from this study were: 52 who did not have congenital Zika syndrome, one with confirmed congenital cytomegalovirus and 21 were still under investigation.

Of 109 infants, 106 data were analyzed by confirmed diagnosis or suspected association to ZIKV infection, although three of these patients were considered as loss $(2.8 \%)$ because they did not return to the outpatient clinic even after the social services made continuous contacts. There were no death reports during this study.

In May 2016, the median age of the follow up patients was of 147 days, with the extremes of between 29 and 299 days on their last consultation date. Approximately half of them (48.6\%) were from Recife Metropolitan Area. In relation to the maternal history observed, the mothers were between the ages of 14 to 40 years old, with the median of 24 and the interquartile range was 20 to 29 years old; $43.0 \%$ reported having fever during the pregnancy; $70.5 \%$ referred the occurrence of skin rash which occurred in $69.4 \%$ of the time in the first trimester of preg- nancy.

Most of the participants of this cohort were born in the maternity at IMIP $(56.0 \%), 56.9 \%$ were females and their birth weight was between 1,135 to 3,855 grams (the median was 2,740 grams and the interquartile range was 2,430 to $2,969 \mathrm{~g}$ ). The measurement of the cephalic perimeter at birth was 22 to $34 \mathrm{~cm}$, the median was $29 \mathrm{~cm}$ and the interquartile range was 27 and $34 \mathrm{~cm}$. Approximately $70.0 \%$ of the diagnosed cases of microcephaly were performed by intrauterine.

Forty children $(37.7 \%)$ presented epileptic seizures which $43.3 \%$ of the cases were classified as spasms, in $22.7 \%$, as generalized tonic seizures, in $20.5 \%$ were partial and $4.5 \%$ were other types of seizures.

The median of days up to the first report on the occurrence of epileptic seizure was 192 days since the date of birth and with the extremes equal to one and 271 days (interquartile range 103 to 217 days). Of the 106 infants, $96.4 \%$ were free of epileptic seizure until the second month of life. On the other hand, $41.8 \%$ of those at risk presented epileptic seizures up to the sixth month of life (Figure 1).

The estimates on the probability of non-occurrence of epileptic seizures throughout the observational period are presented in Table 1.

\section{Figure 1}

The survival curve on the probability of non-occurrence of epileptic seizures during the first nine months of life of the children with congenital ZIKV syndrome.

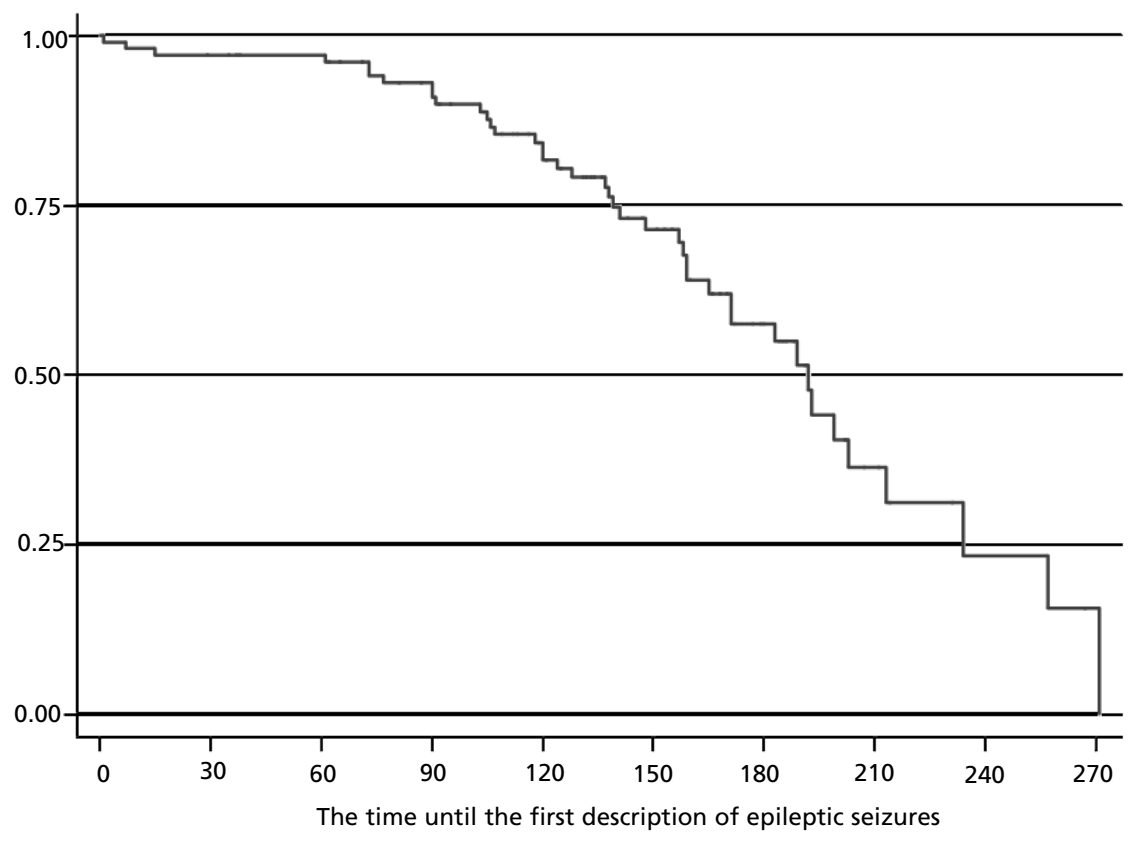


Table 1

\begin{tabular}{|c|c|c|c|c|}
\hline $\begin{array}{l}\text { Time } \\
\text { (in days) }\end{array}$ & Patients at risk & $\begin{array}{l}\text { Event Epileptic } \\
\text { (seizure) }\end{array}$ & $\begin{array}{l}\text { Probability of non- } \\
\text { occurrence of the event }\end{array}$ & $\mathrm{Cl} 95 \%$ \\
\hline 30 & 103 & 3 & 0.97 & $0.91-0.99$ \\
\hline 60 & 100 & 0 & 0.97 & $0.91-0.99$ \\
\hline 90 & 88 & 6 & 0.91 & $0.83-0.95$ \\
\hline 120 & 67 & 8 & 0.81 & $0.72-0.88$ \\
\hline 150 & 43 & 7 & 0.71 & $0.60-0.80$ \\
\hline 180 & 23 & 7 & 0.57 & $0.44-0.68$ \\
\hline 210 & 9 & 6 & 0.36 & $0.21-0.51$ \\
\hline 240 & 4 & 2 & 0.23 & $0.08-0.42$ \\
\hline 270 & 2 & 1 & 0.15 & $0.03-0.36$ \\
\hline
\end{tabular}

\section{Discussion}

An elevated frequency of epileptic seizures was observed on children with congenital ZIKV syndrome. According to the researches in Medline and SciELO database, this is probably one of the first reports on neurological manifestation in children with congenital ZIKV syndrome. According to WHO report on June 2016, 1,520 patients were born with microcephaly worldwide secondary to the congenital infection by ZIKV which our study contemplates $7 \%$ of all these children. ${ }^{2}$

Among the epileptic seizures which started in the first semester of life, spasms were the most frequent (43.3\%). Epileptic seizures occur more frequently in the neonatal period rather than any other period in life with a higher frequency on the first week of life with an estimated incidence of 1.5 to 5.5 for 1,000 live births. 13,14

Epileptic spasm is a rare condition with an incidence of 0.16 to 0.42 for 1,000 live births. Epileptic spasm have been described in association with other congenital infections such as cytomegalovirus and toxoplasmosis. ${ }^{8,15,16}$ Patients with brain impairment due to congenital cytomegalovirus epileptic seizures were observed in $4 \%$ to $11 \%$ of them. 15,16 Unlike the congenital syndrome by ZIKV, the most common seizure type in children with congenital cytomegalovirus infection is generalized.

It would be important to highlight as the limitations for the current study is the fact that the diag-

\section{References}

1. Brasil. Ministério da Saúde. Boletim Microcefalia: Ministério da Saúde investiga 4.291 casos suspeitos no país. [acesso em 26 mai 2016]. Disponível em: http://portalsaude.saude.gov.br/index/php/cidadao/principal/agencia- nosis of ZIKV infection has not been proven serologically in 41 patients although all of them presented brain computed tomographic findings that were described as associated with ZIKV congenital syndrome. ${ }^{7}$ Another aspect was technical difficulty to perform the electroencephalogram due to the reduction of the cephalic perimeter and the patient's restless state. It is noteworthy that the caregiver who reported the occurrence of the epileptic seizure was capable to describe it or make a video on the cell phone. Finally, as the observational period of the present study comprised the first nine months of life which is not possible to assure that other children will not present epileptic seizures later during their development.

The authors intend to present in another study data of the neurological examination emphasizing the more severe the neurological involvement, the higher is the prevalence of epileptic seizures. Furthermore, the type of anti-epileptical medication taken by patients will be described and if presented an effective control on the epileptic seizures.

In conclusion, it was verified that more than one third of the children with congenital ZIKV syndrome presented epileptic seizures $(38.7 \%)$, being the median of days up to the first epileptic seizure reported on the occurrence of 192 days from the date of birth. Further studies are necessary for a better elucidations of the neurological aspects involving the ZIKV infection. saude/22869-microcefalia-ministerio-da-saude-investiga-4291-casos-suspeitos-no-pais. 
2. WHO (World Health Organization). WHO Situation Report Zika Virus microcephaly guillain-barré syndrome 2 june 2016. [acesso em 2 jun 2016]. Disponível em: http://apps.who.int/iris/bitstream/10665/208816/1/zikasitrep_2Jun2016_eng.pdf?ua=1.

3. Pernambuco. Secretaria Estadual de Saúde. Nota técnica SEVS/DGCDA N ${ }^{\circ} 47 / 15$ [Internet]. Pernambuco: Secretaria Estadual de Saúde; 2015 [acesso em 2 jun 2006]. Disponível em: http://portal.saude.pe.gov.br/sites/ portal.saude.pe.gov.br/files/nota_tecnica_47_2015.pdf.

4. Pernambuco. Secretaria Estadual de Saúde. Protocolo Clínico e Epidemiológico para investigação de casos de microcefalia no Estado de Pernambuco. Versão $\mathrm{N}^{\circ} 02$ [Internet]. Pernambuco: Secretaria Estadual de Saúde; 2015 [acesso em 2 jun 2016]. Disponível em: http://portal.saude.pe.gov.br/sites/portal.saude.pe.gov.br/fil es/protocolo_microcefalia_versao02.pdf.

5. Zika virus spreads to new areas - region of the Americas. MMWR Morb Mortal Wkly Rep. 2016; 65: 55-8.

6. Mlakar J, Korva M, Tul N, Popović M, Poljšak-Prijatelj M, Mraz J, Kolenc M, ResmanRus K, Vipotnik TV, Vodušek VF, Vizjak A, Pižem J, Petrovec M, Županc TA. Zika virus associated with microcephaly. N Engl J Med 2016; 374: 951-8.

7. Hazin AN, Poretti A, Turchi Martelli CM, Huisman TA, Microcephaly Epidemic Research Group, Di Cavalcanti Souza Cruz D,Tenorio M, van der Linden A, Pena LJ, Brito C, Gil LH, Barros Miranda-Filho D, Marques ET, Alves JG. Computed Tomographic Findings in Microcephaly Associated with Zika Virus. N Eng J Med. 2016; 374 (22): 2193-5

8. Goldstein J, Slomski J. Epileptic spasms: a variety of etiologies and associated syndromes. J Child Neurol. 2008; 23: 407-14.
9. Boppana SB, Ross SA, Fowler KB. Congenital cytomegalovirus infection: clinical outcome. Clin Infect Dis 2013; 57 Suppl 4:S178.

10. Woods CR. Syphilis in children: congenital and acquired Semin Pediatr Infect Dis 2005; 16:245.

11. Guerina NG, Lee J. Congenital toxoplasmose: treatment, outcome, and prevention. Update 2016 [acesso jun 2016]. Disponível em: http://www.update.com/contents/congenital-toxoplasmosis-treatment-outcome-andprevention?source=see_link\#H4829752

12. Brasil. Ministério da Saúde. Secretaria de Vigilância em Saúde. Departamento de Vigilância das Doenças Transmissíveis. Protocolo de vigilância e resposta à ocorrência de microcefalia e/ou alterações do sistema nervoso central (SNC) / Ministério da Saúde, Secretaria de Vigilância em Saúde, Departamento de Vigilância das Doenças Transmissíveis. Brasília, DF; 2016. 55p. Disponível em: http://combateaedes.saude.gov.br/images/ sala-de-situacao/Microcefalia-Protocolo-de-vigilancia-eresposta-10mar2016-18h.pdf

13. Vasudevan C, Levene M. Epidemiology and aetiology of neonatal seizures. Semin Fetal Neonatal Med. 2013; 18: 185 .

14. Russ SA, Larson K, Halfon N. A national profile of childhood epilepsy and seizure disorder. Pediatrics. 2012; 129: 256.

15. Bale JF, Blackman JA, YutakaSato MPH. Outcome in children with symptomatic congenital cytomegalovirus infection. J Child Neurol. 1989; 4: 131-6.

16. Suzuki Y, Toribe Y, Mogami Y, Yanagihara K, Nishikawa M. Epilepsy in patients with congenital cytomegalovirus infection. Brain Dev. 2008; 30 (6): 420-4.

Received on June 22, 2016

Final version presented on September 28, 2016

Approved on September 29, 2016 